\title{
REPRESENTASI PERAN DAN RELASI GENDER DALAM NOVEL CANTIK ITU LUKA KARYA EKA KURNIAWAN DAN NOVEL NAYLA KARYA DJENAR MAESA AYU
}

\author{
Wiyatmi \\ Fakultas Bahasa dan Seni Universitas Negeri Yogyakarta \\ e-mail: wiyatmi_fbs@yahoo.co.id
}

\begin{abstract}
This study aims to describe the representation of gender relation and gender role and Eka Kurniawan's and Djenar Maesa Ayu's different visions of the two. The data sources were Cantik Itu Luka, a novel by Eka Kurniawan and Nayla, a novel by Djenar Maesa Ayu. The data were analyzed by means of the qualitative descriptive technique through categorization, tabulation, and inference employing the feminist literary criticism theory. The findings are as follows. First, Cantik Itu Luka represents the gender relation dominated by patriarchal power especially in the public domain, while Nayla represents the gender relation leading to superior women against the patriarchal power. Second, Eka Kurniawan views that men have dominant positions in relation to women, while Djenar Maesa Ayu views that men's domination must be opposed by presenting dominant female figures. Third, Eka Kurniawan views that patriarchal domination in gender role still cannot be opposed by women, while Djenar Maesa Ayu views that women must be able to compete with men especially in the public role.
\end{abstract}

Keywords: representation, gender relation, gender role

\section{PENDAHULUAN}

Meskipun perhatian dan pembicaraan terhadap persoalan yang berhubungan dengan isu gender dan perempuan dalam masyarakat di Indonesia telah banyak dilakukan, namun kondisi perempuan dalam hubungannya dengan laki-laki di dalam masyarakat secara umum masih cenderung berada dalam subordinasi. Oleh karena itu, perhatian dan pembicaraan mengenai masalah tersebut masih relevan untuk dilakukan.

Perhatian dan perbicaraan yang berhubungan dengan isu gender dan perempuan tersebut, tidak terlepas dari konsep gender mainstreaming (pengarusutamaan gender) yang berkembang di wacana internasional sejak pertengahan 1985 (Hidajati, 2001). Kesadaran gen- der mainstreaming tersebut tidak hanya berkembang dalam kajian ilmu-ilmu sosial dan hidup dalam tataran empiris di masyarakat, tetapi juga terekspresikan dalam karya sastra. Dalam karya sastra (baca: novel) Indonesia persoalan gender, terutama yang berhubungan dengan relasi dan peran gender sering kali menjadi fokus cerita.

Berdasarkan observasi awal terhadap sejumlah novel Indonesia, tampak bahwa novel-novel Indonesia modern awal seperti Sitti Nurbaya (1922), Layar Terkembang (1948), Belenggu (1954), telah mengangkat isu gender sebagai dasar cerita. Demikian juga dengan novel-novel berikutnya, seperti Trilogi Ronggeng Dukuh Paruk, Pada Sebuah Kapal, Burungburung Manyar, Durga Umayi, Saman, Larung, Tarian Bumi, Geni Jora, Cantik Itu 
Luka, sampai Nayla. Dalam novel-novel tersebut, ada kecenderungan relasi, peran, eksistensi perempuan dalam hubungannya dengan laki-laki dipersoalkan dengan segala kompleksitasnya.

Gambaran tersebut menunjukkan bahwa persoalan gender senantiasa menarik perhatian para sastrawan, sehingga mengangkatnya dalam novel yang ditulisnya. Dalam hal ini novel dapat dianggap sebagai refleksi dari realitas atau novel mencerminkan dan mengekspresikan kehidupan masyarakat. Seperti yang dinyatakan oleh De Bonal (via Wellek dan Warren, 1993) bahwa sastra adalah ungkapan perasaan masyarakat.

Walaupun isu gender dan perempuan telah banyak mendasari cerita sebagian besar novel Indonesia modern sejak 1920-an sampai 2000-an, namun kajian terhadap masalah tersebut, terutama dalam perspektif kritik sastra feminis belum banyak dilakukan. Melalui kajian yang berperspektif feminis gambaran dan suara perempuan yang terefleksi dalam karya sastra diharapkan lebih dapat dipahami. Hal itu karena seperti dikemukakan oleh Reinhartz (2005) bahwa penelitian feminis memiliki tujuan untuk mengindentifikasi penghilangan, penghapusan, dan informasi yang hilang tentang perempuan secara umum. Reinhartz (2005) juga menegaskan bahwa memahami perempuan dari perspektif feminis adalah memahami pengalaman dari sudut pandang perempuan sendiri, yang akan memperbaiki ketimpangan utama cara pandang nonfeminis yang meremehkan aktivitas dan pemikiran perempuan, atau menafsirkannya dari sudut pandang laki-laki di masyarakat atau peneliti laki-laki. Melalui kajian feminis diharapkan juga dapat terungkap kemungkinan adanya kekuatan budaya patriarki yang membentuk citra mengenai perempuan maupun laki-laki, relasi antarkeduanya, ataupun adanya perlawanan terhadap dominasi patriarki yang terefleksi dalam karya-karya sastra tersebut. Seperti dikemukakan oleh Reinhartz (2005) bahwa ciri khas kajian feminis adalah menguak budaya patriarki yang kuat dan bahkan membenci perempuan (misoginis).

Perbedaan gender dalam masyarakat telah melahirkan berbagai pola dan aturan yang berhubungan dengan peran dan relasi gender. Gender mengacu pada suatu sifat yang melekat pada kaum laki-laki maupun perempuan yang dikonstruksi secara sosial maupun kultural (Flax, dalam Nicholson, 1990; Fakih, 2006). Konsep gender dibedakan dengan seks, yang mengacu pada perbedaan jenis kelamin yang bersifat biologis, walaupun jenis kelamin lakilaki sering dikaitkan dengan gender maskulin dan jenis kelamin perempuan berhubungan dengan gender feminin (Fakih, 2006; Abdullah, 2000).

Relasigender adalah polahubungan antara laki-laki dan perempuan yang dikonstuksi secara sosial. Dalam relasi gender kelompok gender tertentu dianggap memiliki kedudukan yang lebih tinggi (mendominasi), yang didominasi, dan yang setara. Dalam masyarakat patriarki, laki-laki dianggap memiliki kedudukan yang dominan, semantara perempuan berada dalam subordinat. Relasi yang tidak setara dan lebih bersifat dominasi-subordinasi tersebut pada akhirnya memberi peluang munculnya berbagai bentuk kekerasan terhadap perempuan baik di dalam wilayah rumah tangga seperti kekerasan fisik, psikis, dan ekonomi.

Peran gender berhubungan dengan pembagian peran laki-laki dan perempuan yang secara sosial dirumuskan berdasarkan polarisasi stereotipe seksual maskulinitas-feminitas. Contoh peran gender, misalnya laki-laki ditempatkan sebagai pemimpin dan pencari nafkah karena dikaitkan dengan anggapan bahwa laki-laki adalah

Representasi Peran dan Relasi Gender dalam Novel Cantik Itu Luka Karya Eka Kurniawan 
makhluk yang lebih rasional, lebih kuat serta identik dengan sifat-sifat superior lainnya dibandingkan dengan perempuan, sementara perempuan dianggap memiliki tugas utama untuk melayani suami, kalau perempuan bekerja, maka dianggap sebagai pekerjaan sambilan atau membantu suami, karena nafkah dianggap sebagai tugas suami (Fakih, 2006). Selanjutnya, relasi gender yang tidak setara juga menimbulkan persoalan dalam hubungannya dengan seksualitas dan perkawinan, hingga menimbulkan kekerasan seksual.

Ketika ketiga isu gender tersebut digambarkan dalam novel, diasumsikan adanya perbedaan perspektif antara pengarang perempuan dengan laki-laki, sehingga perlu dilihat perbedaan perspektif tersebut. Seperti dikemukakan oleh (Humm, 1986) bahwa adanya perbedaan konstruksi linguistik feminis, yang digunakan untuk mendekonstruksi hirarki gender dalam sastra dan masyarakat. Di samping itu, rentang waktu yang dinamis, juga memungkinkan adanya perbedaan dan perkembangan isu-isu gender dan penggambarannya dalam novel. Oleh karena itu, perlu dilihat perkembangan representasi isu gender dalam novel-novel Indonesia modern antara 1920-an sampai 2000-an.

Dalam paradigma perkembangan kritik sastra, kritik sastra feminis dianggap sebagai kritik yang bersifat revolusioner yang ingin menumbangkan wacana yang dominan yang dibentuk oleh suara tradisional yang bersifat patriarki (Ruthven, 1985). Sejak bangkitnya kembali gerakan feminis tahu 1960-an di Amerika, para ilmuwan yang feminis sadar bahwa studi dan penelitian sosial selama ini cenderung male bias dan mengusung pendekatan kuantitatif konvensional yang sama sekali tidak mengungkap persoalan yang dihadapi perempuan (Sihite, 2007). Aliran feminisme mengritik ilmu pengetahuan so- sial konvensional sebagai androsentris dan bias laki-laki. Ilmu sosial mengungkapkan data dan mengalasisnya melalui sudut pandang laki-laki; menggeneralisikan temuan mereka sebagai relevan untuk semua orang tanpa memperhatikan gender, ras, atau kelas (Holzenr, via Sihite, 2007).

Tujuan utama kritik sastra feminis adalah menganalisis relasi gender, situasi ketika perempuan berada dalam dominasi laki-laki (Flax, dalam Nicholson, 1990). Melalui kritik sastra feminis akan dideskripsikan opresi perempuan yang terdapat dalam karya sastra (Humm, 1986).

Kaum feminis berpendapat bahwa epistemologi tradisional, baik sengaja maupun tidak, secara sistematis telah mengeluarkan perempuan dari kemungkinan menjadi agen ilmu pengetahuan (Harding, via Sihite, 2007). Mereka menyatakan bahwa suara ilmu pengetahuan bersifat maskulin, sejarah ditulis dari sudut pandang laki-laki. Laki-laki selalu menjadi subjek penelitian sosiologi tradisional. Oleh karena itu, kaum feminis telah mengajukan teori pengetahuan alternatif yang melegitimasi perempuan sebagai knowers (Harding, via Sihite, 2007). Kalangan feminis menegaskan bahwa tidak hanya dibutuhkan penelitian yang memberi pemahaman akan kehidupan, pengalaman, cita-cita dan kesulitan perempuan, juga dibutuhkan penelitian yang memberi, yaitu solusi atau pemecahan masalah untuk memperbaiki kehidupan mereka (Harding, via Sihite, 2007).

Senada dengan yang dikemukakan oleh Harding tersebut, dalam konteks kritik sastra, Humm (1986) menyatakan bahwa penulisan sejarah sastra sebelum munculnya kritik sastra feminis, dikonstruksi oleh fiksi laki-laki. Oleh karena itu, kritik sastra feminis melakukan rekonstruksi dan membaca kembali karya-karya tersebut dengan 
fokus pada perempuan, sifat sosiolinguistiknya, mendeskipsikan tulisan perempuan dengan perhatian khusus pada penggunaan kata-kata dalam tulisannya.

Berdasarkan latar belakang tersebut, perlu dilakukan kajian yang berhubungan dengan isu-isu gender yang terefleksi dalam novel Indonesia, khususnya dengan menggunakan perspektif kritik sastra feminis. Dari berbagai isu gender yang ada, ada dua persoalan yang perlu dipahami lebih lanjut, antara lain berkaitan dengan relasi dan peran gender yang terefleksi dalam novel Indonesia.

\section{METODE}

Penelitian ini menggunakan metode yang bersifat deskripstif kualitatif. Metode deskriptif dapat diuaraikan sebagai prosedur pemecahan masalah yang diselidiki dengan menggambarkan keadaan subjek atau objek penelitian pada saat sekarang berdasarkan fakta yang tampak atau sebagaimana adanya. Metode ini juga bertujuan untuk melukiskan secara sistematis fakta atau karakteristik subjek penelitian secara faktual dan cermat. Dalam penelitian ini metode tersebut digunakan untuk mendeskrpsikan dan memahami peran dan relasi gender yang terefleksi dalam novel Cantik Itu Luka dan Nayla dalam perspektif kritik sastra feminis.

Sumber data adalah novel Cantik Itu Luka karya Eka Kurniawan, Grame- dia Pustaka Utama, 2006 dan Nayla karya Djenar Maesa Ayu, Gramedia Pustaka Utama, 2006. Data berupa unit sintaksis yang mengandung informasi yang berkaitan dengan masalah penelitian yang diambil dari novel yang menjadi objek penelitian. Data tersebut dicatat dalam kartu data dan diklasifikasikan sesuai dengan informasi yang berhubungan dengan masalah yang diteliti.

Analisis data dilakukan dengan teknik deskriptif kualitatif melalui kegiatan kategorisasi, tabulasi, dan inferensi. Kategorisasi digunakan untuk mengelompokkan data berdasarkan kategori yang telah ditetapkan. Tabulasi digunakanuntukmerangkumkeseluruhan data dalam bentuk tabel. Inferensi digunakan untuk menginterpretasikan dan menyimpulkan hasil penelitian sesuai dengan permasalahan penelitian. Dalam penelitian ini inferensi didasarkan pada kerangka teori kritik sastra feminis.

\section{HASIL DAN PEMBAHASAN}

Sesuai dengan rumusan masalah, penelitian ini mengkaji representasi relasi gender, peran gender, perbedaan pandangan antara Eka Kurniawan dengan Djenar Maesa Ayu mengenai relasi dan peran gender dalam novel mereka. Hasil penelitian terhadap kedua novel tersebut adalah sebagai berikut.

\section{Tabel 1 Representasi Relasi}

\begin{tabular}{llcc}
\hline No. & Relasi gender & \multicolumn{2}{c}{ Novel } \\
& & CIL & Nay \\
\hline 1. & Perempuan dominan & 26 & 28 \\
2. & Laki-laki dominan & 50 & 16 \\
\hline
\end{tabular}

Representasi Peran dan Relasi Gender dalam Novel Cantik Itu Luka Karya Eka Kurniawan 
Tabel 2 Representasi Peran Gender dalam Novel

\begin{tabular}{llcc}
\hline No. & Peran Gender & \multicolumn{2}{c}{ Novel } \\
& \multicolumn{1}{c}{ CIL } & Nay \\
\hline 1. $\quad \begin{array}{l}\text { Laki-laki di sektor publik (penulis, sopir pribadi, } \\
\text { sopir taksi, Kyahi, tukang gali kubur dan penjaga } \\
\text { kuburan, tentara, Polisi Rayon Militer, Preman, } \\
\text { nelayan, ketua partai politik) }\end{array}$ & 6 & 4 \\
2. $\quad \begin{array}{l}\text { Perempuan di sektor publik (model, perancang } \\
\text { busana, polwan, juru lampu diskotik, peragawati, } \\
\text { perawat rumah rehabilitasi anak-anak } \\
\text { bermasalah/eksnarkoba) }\end{array}$ & 2 \\
$\begin{array}{l}\text { Perempuan di sektor domestik (ibu rumah tangga, } \\
\text { pembantu rumah tangga) }\end{array}$ & 2 \\
\hline
\end{tabular}

Tabel 3 Perbedaan Visi antara Eka Kurniawan dan Djenar Maesa Ayu dalam Memandang Relasi Gender dalam Novel Mereka

\begin{tabular}{lll}
\hline No. & Pengarang & Pandangan terhadap Relasi Gender \\
\hline 1. & $\begin{array}{l}\text { Djenar Maesa } \\
\text { Ayu }\end{array}$ & $\begin{array}{l}\text { Dominasi laki-laki harus dilawan, seorang perempuan } \\
\text { harus dapat mandiri, hubungan lesbian merupakan } \\
\text { salah satu cara menolak dominasi laki-laki. }\end{array}$ \\
2. & $\begin{array}{l}\text { Eka } \\
\text { Kurniawan }\end{array}$ & $\begin{array}{l}\text { Laki-laki memiliki posisi yang dominan, perempuan } \\
\text { belum berhasil melawan dominasi laki-laki. }\end{array}$ \\
\hline
\end{tabular}

Tabel 4 Perbedaan Visi antara Eka Kurniawan dengan Djenar Maesa Ayu dalam Memandang Peran Gender dalam Novel Mereka

\begin{tabular}{lll}
\hline No. & Pengarang & Pandangan terhadap Peran Gender \\
\hline 1. & Djenar Maesa & $\begin{array}{l}\text { Masih terdapat ketidakadilan dalam peran gender. } \\
\text { Perempuan memiliki peran ganda si sektor domenstik } \\
\text { maupun publik, sementara laki-laki tidak ada yang } \\
\text { terlibat di sektor domestik. }\end{array}$ \\
& Eka & $\begin{array}{l}\text { Masih terdapat ketidakadilan dalam peran gender. } \\
\text { Perempuan hamper tidak ada yang terlibat di sektor } \\
\text { publik. Pekerjaan Dewi Ayu sebagai pelacur juga untuk } \\
\text { melayani laki-laki. }\end{array}$ \\
\hline
\end{tabular}


Dari hasil penelitian tampak bahwa novel Cantik Itu Luka merepresentasikan relasi dan peran gender yang menunjukkan adanya dominasi patriarki, baik di sektor domestik maupun publik. Sebaliknya, Nayla mencoba menggambarkan posisi perempuan yang lebih dominan, baik di sektor domestik maupun publik.

Dominasi patriarki dalam Cantik Itu Luka, terutama tampak dalam tindak perkosaan yang dilakukan oleh tentara Jepang terhadap tokoh Dewi Ayu dan kawan-kawannya pada masa penjajahan Jepang, perkosaan yang dilakukan Krisan terhadap Rengganis, perkosaan yang dilakukan oleh Shodanco terhadap Alamanda (sebelum keduanya menikah), serta pemaksaan hubungan seks dengan kasar yang dilakukan oleh Shodancho terhadap istrinya, Alaman$\mathrm{da}$, serta pembunuhan yang dilakukan Krisan terhadap Rengganis karena Renganis yang hamil setelah diperkosa menuntut untuk dinikahinya. Beberapa data berikut merupakan contoh adanya dominasi patriarki tersebut.

Kemudian tentara-tentara itu mulai mengambil gadis-gadis tersebut satu per satu, dalam satu perkelaian yang dengan mudah mereka menangkan. Mereka membawa gadis-gadis itu ke dalam jepitan tangan, bagaikan membawa kucing sakit, dan mereka meronta-ronta penuh dengan kesia-siaan... (h.96)

Beberapa di antara mereka adalah orang-orang yang sama dengan pembunuh beberapa prajurit Belanda dan memerkosa Dewi Ayu bersama temantemannya sebelum tentara Inggris datang dan melindungi gadis-gadis itu... (h.165)

Alamanda tak hanya ingin melolong, ia bahkan ingin mencekik lehernya sendiri agar mati sebelum laki-laki di depannya berbuat lebih jauh dari itu (h. 236-237).

Sang Shodancho tiba-tiba menangkap tubuhnya dari belakang, menarik pakaian tidur istrinya begitu kuat hingga sobek terkoyak dan menanggalkannya (h.252).

Kedua tangan dan kedua kakinya terikat ke empat sudut tempat tidur. Alamanda mencoba bangun dan menarik tali pengikat, namun rupanya ikatan itu begitu kencang sehingga apa yahg terjadi hanya membuat pergelangan tangan maupun kakinya terasa sakit (h.255).

Selama sembilan bulan Krisan diteror rasa takut bahwa orang, Terutama Maman Gendeng dan Maya Dewi, dan juga ibunya, tahu bahwa Krisanlah yang menyetubuhi Rengganis Si Cantik. Ia merencanakan membunuh gadis itu di gubuk gerilya, untuk mengubur semua cerita tersebut, tapi kemudia ia membunuhnya di atas perahu, dan membuang mayatnya ke laut. (h. 475).

Kutipan (1) dan (2) menggambarkan perkosaan dan kekejaman yang dilakukan oeh tentara Jepang terhadap gadis-gadis yang berasal dari keluarga Belanda yang ditawan mereka, salah satu dari gadis tersebut adalah Dewi Ayu. Kutipan (3) menggambarkan perkosaan yang dilakukan Shodanco terhadap Alamanda. Karena merasa telah dirusak oleh Shodanco, selanjutnya Alamanda ingin menghukum Shodanco, dengan menuntut pernikahan. Namun, sejak malam pertama sambai beberapa tahun kemudian, Alamanda menolak melakukan hubungan seksual dengan Shodanco yang telah menjadi suaminya. Untuk melindungi dirinya, Alamanda menggunakan celana dalam bergembok. Shodanco tetap 
menunggu kelengahan Alamanda. Pada suatu hari Shodanco mendobrak paksa kamar mandi ketika istrinya sedang mandi dan membuang celana dalam bergembok tersebut. Akibatnya, Alamanda pun harus mengalami pemaksaan hubungans eksual yang kasar dan menyakitkan (kutipan 4 dan 5). Kutipan

(6) menggambarkan bagaimana Krisan, yang telah memperkosa Rengganis di sebuah kamar mandi sekolah, pada akhirnya tega membunuh Rengganis, yang sebenarnya adalah saudara sepupunya sendiri. Data-data tersebut secara jelas menunjukkan adanya dominasi patriarki. Beberapa tokoh perempuan telah berusaha melawan domonasi tersebut, baik melalui kata-kata maupun perbuatan, terapi tidak ada yang berhasil menghentikannya.

Feminisme

memandang perkosaan (rape) yang dilakukan oleh para laki-laki terhadap perempuan sebagai tindakan dan institusi sosial yang melanggengkan dominasi patriarki (Humm, 2007:388). Menurut para feminis radikal, patriarki melegitimasi perkosaan sebagai hal yang "normal", kerena dalam pandangan patriarki, perempuan dianggap sebagai objek seksual, sementara laki-laki dianggap mempunyai dorongan untuk melakukan dorongan heteroseksual (Humm, 2007:389). Dalam konteks ini, maka gambaran tindak perkosaan yang cukup banyak dalam novel Cantik Itu Luka menunjukkan bahwa novel tersebut, yang ditulis oleh pengarang berjenis kelamin laki-laki tampak melanggengkan kekuatan patriarki.

Profesi yang beragam, yang identik dengan pekerjaan laki-laki yang terdapat dalam Cantik Itu Luka, seperti tentara Jepang, Kyahi (Jahro), tukang gali kubur dan penjaga kuburan (Kamino), Polisi Rayon Militer (Shodanco), Preman (Maman Gendheng), nelayan (teman-teman Kamerad Kliwon), ketua partai politik (Kamerad Kliwon) juga menunjukkan adanya bias gender dalam peran sosial maupun domestik. Perempuan dalam novel tersebut memiliki peran yang terbatas, sebagai ibu rumah tangga dan pembantu rumah tangga. Pekerjaan Dewi Ayu sebagai pelacur dan Mama Kalong sebagai germo, kalau itu dianggap sebagai peran di sektor publik diciptakan dalam rangka melayani nafsu seksual laki-laki. Perempuan dalam novel ini memang digambarkan mencoba melawan dominasi patriarki, tetapi belum berhasil. Perlawanan yang dilakukan Dewi Ayu sebagai pelacur, tampak dari bagaimana dia memasang tarif yang sangat tinggi, sehingga hanya orang-orang kaya saja yang dapat membayarnya.

Berbeda dengan Cantik Itu Luka yang merepresentasikan dominasi patriarki, Nayla cenderung merepresentasikan sosok perempuan yang dominan, baik di sektor domestik maupun publik. Dalam novel Nayla, Maesa Ayu merepresentasikan perempuan yang lebih dominan dalam hubungannya dengan laki-laki. Digambarkan tokoh ibu yang bertahan hidup dan membesarkan anak perempuannya tanpa suami. Kalaupun ibu berhubungan dengan para laki-laki, yang bukan suaminya, mereka dijadikan sumber uang. Ibu juga selalu menekankan kepada anak perempuannya,Nayla untuk bisa mandiri. Berbeda dengan tokoh perempuan dalam Cantik Itu Luka yang lebih banyak berperan di sektor domestik, tokoh-tokoh perempuan dalam Nayla memiliki peran di sektor publik antara lain sebagai model, perancang busana, polwan, juru lampu diskotik, peragawati, perawat rumah rehabilitasi anak-anak bermasalah/eksnarkoba. Peran domestik yang dijalani ibu Nayla, merupakan peran ganda karena dia juga seorang model. Beberapa data berikut merupakan contoh, bagaimana perempuan (Ibu Nayla), seperti apa pun kuali- 
tasnya, mencoba menjadi perempuan yang dominan, bahkan memiliki nafsu untuk mendominasi laki-laki.

Aku tak butuh mereka. Lihat betapa banyak laki-laki yang takluk kepadaku. Lihat betapa mereka rela menyerahkan jiwa dan raganya hanya untukku. Kamu pun harus bisa seperti aku. ... Dan dengan sendirinya kamu tak akan sudi mencarinya. Kamu akan memilih lebih baik hanya punya aku, ibumu, ketimbang punya ayah yang tega meninggalkan anaknya (h. 8).

Mereka adalah binatang yang rakus, Ibu tinggal memasak atau menyediakan hidangan khusus. Terbukti memang, binatang-binatang itu tak berdaya di depan ibu. Apa yang ibu butuhkan, mereka dengan sesuka hati menyediakan. Apa yang ibu minta, mereka dengan sukarela memberikan (h. 39).

Ya, Om Billy sangat mengagumi Ibu. Di mata Om Billy, Ibu adalah perempuan cantik dan mandiri. Ibu bisa menjadi seorang ibu sekaligus ayah. Sebagai seorang peragawati ternama di jamannya, Ibu mampu membagi waktu antara pekerjaan dan mengurus rumah. (h.95).

Penolakan terhadap dominasi laki-laki dalam Nayla, juga tampak pada pilihan Juli dan Nayla untuk menjadi seoarang lesbian, yang memilih orientasi seksual terhadap sesama perempuan, seperti tampak pada kutipan berikut.

Perawakan dan sikap Juli tak ubahnya seorang laki-laki. Ia memang pecinta sesama jenis. Tapi kelainannya bukan faktor genetik. Keluarganya normal-normal saja, akunya. Normal dalam pengertian, bukan pencinta sesama jenisnya. (h.4).
Sekarang pun dengan kekasihnya yang seorang model mereka sering bercinta dengann cara saling memasuki vagina satu sama lain dengan jari mereka (h.4).

Saya juga punya pacar. Bukan laki-laki, tapi perempuan. Yang laki-laki cuma untuk hit and run. Mereka benar-benar makhluk yang menyebalkan, sekaligus menggiurkan. (h.54).

Di samping memilih hubungan lesbian, tokoh Juli dan Nayla juga sampai pada kesadaran untuk merenungkan dan menolak mitos-mitos yang diciptakan dalam budaya patriarki demi kepentingan laki-laki, seperti tampak pada kutipan berikut.

Laki-laki menciptakan mitos perempuan ideal. Perempuan ideal adalah perawan. Alat kelamin perempuan yang ideal adalah tidak kelebihan cairan dan otot vaginanya kencang. (h.84)

Bahwasannya perempuan harus perawan, harus pandai mengatur keuangan, harus sabar, harus bisa memasak, harus bisa memberi keturunan, harus pandai memuaskan suami di ranjang. Sementara syarat-syarat menjadi laki-laki hanya satu, pandai-pandailah mencari uang. (h.85).

Dengan merepresentasikan sosok perempuan yang selalu ingin kuat, mandiri, dan menguasai laki-laki dalam novel Nayla tampak adanya semangat feminisme radikal dalam novel tersebut. Feminisme radikal menyatakan bahwa relasi gender yang bersifat patriarki menimbulkan penindasan terhadap perempuan, karena perempuan ditempatkan ke dalam kelas inferior dibandingkan dengan kelas laki-laki dengan menggunakan basis gen- 
der. Oleh karena itu, perempuan harus melakukan kontrol terhadap tubuh dan kehidupan mereka (Humm, 2007).

Pandangan tokoh Juli dan Nayla mengenai laki-laki yang minor (seperti: laki-laki Cuma untuk hit and run. Mereka benar-benar makhluk yang menyebalkan, sekaligus menggiurkan) serta pilihan mereka untuk menjadi lesbian, juga sesuai dengan keyakinan feminisme radikal yang melihat relasi male-female sebagai hal yang menindas, sehingga perempuan harus menghindari hubungan tersebut (Humm, 2007; Tong, 1998).

Ada pandangan yang berbeda antara kedua pengarang yang berjenis kelamin berbeda tersebut dalam memandang relasi dan peran gender. Melalui novelnya, Eka Kurniawan cenderung memandang bahwa laki-laki memiliki posisi yang dominan, sementara perempuan walaupun telah mencoba melawannya, tetapi belum berhasil, tetap saja kalah. Di samping itu, peran-peran sosial (profesi yang penting dalam masyarakat) pun masih dikuasai oleh laki-laki. Djenar Maesa Ayu, mencoba melawan semua itu dengan menghadirkan sosok perempuan yang dominan, mandiri, bahkan terkesan terlalu kejam dan disiplin dalam pandangan anaknya. Pilihan Juli dan Nayla untuk menjadi lesbian juga menunjukkan penolakannya menjadi korban kekuasaan patriarki.

Dalam perspektif kritik sastra feminis perbedaan representasi relasi dan peran gender, serta pendangan Eka Kurniawan dengan Djenar Maesa Ayu terhadap relasi dan peran gender berhubungan dengan ideologi yang mendasari penulisan novel mereka. Ideologi familialialisme atau yang lebih dikenal dengan patriarki mendasari penulisan novel Cantik Itu Luka. Semantara ideologi feminisme, khususnya feminisme radikal libetarian mendasari penulisan novel Nayla. Feminisme memandang patriarki sebagai suatu sitem otoritas laki-laki yang menindas perempuan melalui institusi sosial, politik dan ekonomi (Humm, 2007). Berdasarkan sejumlah data yang telah dianalisis tampak jelas bagaimana novel Cantik Itu Luka telah merepresentasikan berbagai bentuk pendindasan terhadap perempuan yang menguatkan adanya kekuatan patriarki. Dalam masyarakat patriarki, kecantikan yang dimiliki perempuan bahkan telah menjelma menjadi sebuah komoditas yang keberadaannya untuk melayani dan memuaskan laki-laki. Karena perempuan tidak memiliki kekuatan untuk melawan dominasi patriarki tersebut, maka kecantikan yang dimiliki perempuan adalah penyebab timbulnya luka atau penderitaan.

Dengan merepresentasikan relasi dan peran gender yang cenderung mengunggulkan perempuan, Nayla jelas ditulis berdasarkan ideologi feminisme yang menolak dominasi patriarki, tetapi sebaliknya menginginkan adanya sesejajaran, atau bahkan cenderung keunggulan dari perempuan. Sebuah pandangan yang sesuai dengan feminism radikal. Lesbianisme yang digambarkan di dalam novel tersebut merepresentasikan pandangan feminism radikal yang berhubungan dengan hakikat seksualitas perempuan. Seperti dinyatakan oleh Humm (2007) bahwa beberapa feminis menyatakan bahwa seksualitas perempuan hanya benar-benar direpresentasikan dalam hubungan lesbian.

\section{SIMPULAN}

Berdasarkan hasil penelitian dan pembahasan yang telah dilakukan,disimpulkan hal-hal sebagai berikut. Pertama, novel Cantik Itu Luka 
merepresentasikan relasi gender yang didominasi oleh kekuatan patrriarki, perempuan masih ditempatkan pada posisi yang inferior, objek dari kekuatan laki-laki. Hal ini berbeda dengan novel Nayla yang merepresentasikan relasi gender yang mengarah pada perempuan yang superior, perempuan yang mencoba untuk melawan kekuatan patriarki. Perlawanan tersebut dalam Nayla bahkan diwujudkan dengan semangat dan tindakan lesbianisme yang dipilih tokoh perempuan. Kedua, novel Cantik Itu Luka merepresentasikan peran gender yang didominasi oleh kekuatan patriarki terutama dalam sektor publik. Berbagai profesi penting dalam kehidupan sosial dikuasai oleh tokoh laki-laki, perempuan ditempatkan di sektor domestik dan sektor publik yang keberadaannya pun untuk melayani kepentingan laki-laki (pelacur dan germo). Ketiga, melalui novelnya Eka Kurniawan memandang bahwa Laki-laki memiliki posisi yang dominan dalam relasinya dengan perempuan, sementara Djenar Maesa Ayu memandang bahwa dominasi laki-laki tersebut harus dilawan, dengan memunculkan sosok perempuan yang dominan. Keempat, melalui novelnya Eka Kurniawan memandang bahwa dominasi patriarki dalam peran gender belum dapat dilawan oleh perempuan. Perempuan hampir tidak ada yang terlibat di sektor publik. Pekerjaan Dewi Ayu sebagai pelacur juga untuk melayani laki-laki. Sebaliknya, Djenar Maesa Ayu memandang bahwa perempuan harus mampu bersaing dengan laki-laki, khususnya dalam peran publik. Dengan merepresentasikan relasi dan peran gender yang cenderung mengunggulkan perempuan, Nayla jelas ditulis berdasarkan ideologi feminisme yang menolak dominasi patriarki, tetapi sebaliknya menginginkan adanya kesejajaran, atau bahkan cenderung keunggulan dari perempuan.

\section{UCAPAN TERIMA KASIH}

Artikel ini diangkat dari penelitian yang dilaksanakan pada tahun 2008 dengan anggaran DIKS FBS UNY. Oleh karena itu, ucapan terima kasih disampaikan kepada BPP Penelitian FBS UNY yang telah mendanai dan menyelenggarakan seminar hasil penelitian. Selanjutnya ucapan terima kasih disampaikan kepada dua reviewer anonim yang telah membaca, mengoreksi dan memberi masukan terhadap artikel ini.

\section{DAFTAR PUSTAKA}

Abdullah, Irwan. 2000. "Penelitian Berwawasan Gender dalam Ilmu Sosial" dalam Humaniora. Vol. XVI, No. 3.

Fakih, Mansoer. 1998. “Diskriminasi dan Beban Kerja Perempuan: Perspektif Gender," dalam Bainar, Ed. Wacana Perempuan dalam Keindonesiaan dan Kemodernan. Jakarta: Pustaka Cidesindo bekerja sama dengan Universitas Islam Indonesia dan Yayasan IPPSDM.

Fakih, Mansoer. 2006. Analisis Gender E Transformasi Sosial. Yogyakarta: Pustaka Pelajar.

Flax, Jane. 1990. "Postmodernism and Gender Relation in Feminst Theory," in Nichloson, Linda J. Feminism/Postmodernism. New York and London: Routledge.

Hidajati, Miranti. 2001. "Perempuan dan Pembangunan," dalam Jurnal Perempuan, nomor 17. Jakarta: Yayasan Jurnal Perempuan.

Humm, Maggie. 1986. Feminist Criticism: Woman as Contemporary Ctritics. Brighton, Sussex: The Harvester Press Limited.

Humm, Maggie. 2007. Ensiklopedia Feminisme. Terjemahan Mundi Rahayu. Yogyakarta: Fajar Pustaka Baru. 
Nicholson, Linda J. Feminsm/ Postmodernism. New York and London: Routledge.

Reinharz, Shulamit. 2005. Metode-metode Feminis dalam Penelitian Sosial. Diterjemahkan dalam Bahasa Indonesia oleh Lisabona Rahman dan J. Bambang Agung. Jakarta: Woman Reseach Institute.

Ruthven, K.K. 1985. Feminist Letarary Studies an Introduction. Cambridge, New York, Port Chester, Melbourne, Sydney: Cambridge University Press.
Sihite, Romany. 2007. Perempuan, Kesetaraan, \& Keadilan. Jakarta: Rajawali Press.

Tong, Rosemarie Putnam. 2006. Feminist Thought. Diterjemahkan ke dalam Bahasa Indonesia oleh Aquarini P. Prabasmara. Yogyakarta \& Bandung: Jalasutra.

Wellek, Rene dan Austin Warren. 1993. Teori Kesusastraan. Terjemahan Melani Budianta. Jakarta: Gramedia. 